Market Civilization and Its Clash with Terror

Author(s): Michael Mousseau

Source: International Security, Vol. 27, No. 3 (Winter, 2002-2003), pp. 5-29

Published by: The MIT Press

Stable URL: http://www.jstor.org/stable/3092112

Accessed: 31-05-2017 13:53 UTC

\title{
REFERENCES
}

Linked references are available on JSTOR for this article:

http://www.jstor.org/stable/3092112?seq=1\&cid=pdf-reference\#references_tab_contents You may need to $\log$ in to JSTOR to access the linked references.

JSTOR is a not-for-profit service that helps scholars, researchers, and students discover, use, and build upon a wide range of content in a trusted digital archive. We use information technology and tools to increase productivity and facilitate new forms of scholarship. For more information about JSTOR, please contact support@jstor.org.

Your use of the JSTOR archive indicates your acceptance of the Terms \& Conditions of Use, available at http://about.jstor.org/terms

The MIT Press is collaborating with JSTOR to digitize, preserve and extend access to International Security 


\section{Market Civilization and Its Clash with Terror}

Michael Mousseau

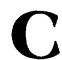

lausewitz's dictum

that war is politics by other means is a reminder that the primary goal of the war against terror is not to defeat and eliminate those who aim to attack the United States and its allies. Rather it is to enhance the security of the American people and their allies. These goals are the same only if terrorist organizations such as al-Qaeda are isolated groups of criminals that need only be found and dealt with swiftly. But if al-Qaeda and its associated groups represent the values and beliefs of substantial numbers of people, and all signs indicate that this is the case, then defeating these groups will not end the struggle against terror. Only by changing the values and beliefs of supporters of terrorist groups can the United States and its allies expect to achieve this objective.

To win the war against terror, the United States and its allies must have both a military strategy and a political strategy. Achieving political victory requires an understanding of the social basis of terror-that is, the values and beliefs that legitimate the use of extreme and indiscriminate violence against the civilian populations of out-groups. Such understanding will not reveal much about terror groups that seem to lack social support, such as the Basque terrorists in Spain, but it will help to reduce the influence of those groups that appear to enjoy widespread support, such as al-Qaeda. Seeking to understand the motivations of terrorists, however, should not be confused with empathizing with them or acquiescing on issues that terrorists and their supporters claim motivate them.

Some scholars have sought to link poverty with terror. Poverty, they argue, fosters terror because it creates a sense of hopelessness, restricts educational opportunity, and produces frustration over inequality. ${ }^{1}$ The direct causal linkages between poverty and terror are more elusive than scholars suggest, how-

Michael Mousseau is Associate Professor of International Relations at Koç University in Istanbul, Turkey.

It is with profound gratitude that the author dedicates this article to the memory of Stuart A. Bremer (1944-2002), whose brilliance, affection, and scholarly leadership will be deeply missed by his many students and colleagues.

1. For a summary of these views, see Martha Crenshaw, "The Causes of Terrorism," in Charles W. Kegley Jr., ed., International Terrorism: Characteristics, Causes, Controls (New York: St. Martin's, 1990), pp. 113-126. For recent examples, see Samuel P. Huntington, "The Age of Muslim Wars," Newsweek, December 17, 2001, pp. 42-48; and James D. Wolfensohn, "Making the World a Better and Safer Place: The Time for Action Is Now," Politics, Vol. 22, No. 2 (May 2002), pp. 118-123. 
ever. Indeed I am unaware of any comprehensive explanation in print for how poverty causes terror. Nor has there been any demonstrated correlation between the two. ${ }^{2}$ Nevertheless, there has been a chorus of calls to increase foreign aid as a tool in the fight against terror. ${ }^{3}$ Absent an understanding of the social origins of this phenomenon, however, there is little reason to believe that greater foreign aid will have any significant positive effect. It may even increase the terrorist threat.

In this article, I argue that the social origins of terror are rooted less in poverty-or in growing discontent with U.S. foreign policy-and more in the values and beliefs associated with the mixed economies of developing countries in a globalizing world. I show how liberal-democratic values and beliefs are embedded in the economic infrastructure that prevails in market democracies, and how collective-autocratic values and beliefs are embedded in clientalist economies. As a result of globalization, these values and beliefs are increasingly clashing in the mixed market-clientalist economies of the developing world, triggering intense antimarket resentment directed primarily against the epitome of market civilization: the United States. This study builds on several generations of research in anthropology, economics, political science, and sociology; it explains much of the historical record of sectarian terror around the globe and, most important, suggests how the United States and its allies can combat it.

The article is organized as follows. After reviewing the literature on rational and cultural explanations for terror, I show how market democracies constitute a global civilization based not on interstate trade but on common liberal values and beliefs that thrive in market economies. I then discuss the clash of these liberal values and beliefs with the values and beliefs embraced in many parts of the developing world. I next demonstrate how clientalist values are a necessary condition for the resort to terrorist violence. I conclude with recommendations for developing a political strategy to win the war on terror.

\section{Rational and Cultural Explanations for Terror}

The academic literature offers two explanations, one rational and the other cultural, for why some societies support terrorism. The first view holds that ter-

2. Alan B. Krueger and Jitka Maleckova, "The Economics and the Education of Suicide Bombers: Does Poverty Cause Terrorism?" New Republic, June 24, 2002, pp. 27-33.

3. Many of these calls are made in the media. In the academic literature, see Ivo H. Daalder and James M. Lindsay, "Nasty, Brutish, and Long: America's War on Terrorism," Current History, December 2001, pp. 403-408; and Wolfensohn, "Making the World a Better and Safer Place." 
rorism is a rational strategy for dealing with particular socioeconomic grievances in societies where the "paths to legal expression of opposition are blocked." "Governments that fail to meet the basic welfare and economic needs of their peoples and suppress their liberties," argues Samuel Huntington, "generate violent opposition to themselves and to Western governments that support them. ${ }^{\prime 5}$ In the context of the current war on terror, the Arab world is said to need "a managed political opening . . . that introduces pluralism into ... political life." ${ }^{\prime 6}$

Rational explanations of the origins and social support of terror accord well with mainstream views in academia. Realism, for instance, assumes that values and beliefs play no role in the origin or resolution of conflict, ${ }^{7}$ and thus the resort to terror is a predictable strategy of the weak. Liberal institutionalists argue that democracies are more likely than other kinds of states to resolve their internal (and external) differences through peaceful means. ${ }^{8}$ In addition, they predict that societies in autocracies are more likely to experience violence and to support terror as an acceptable political tool. Although many developing countries have not produced widespread support for terrorism, such support does seem to be more pervasive in the developing world, especially in those countries lacking stable democratic institutions (e.g., Egypt, Indonesia, and Pakistan).

Rational models for explaining the social support of terror have several major weaknesses. The historical record, for instance, does not accord with the proposition that democracies are less likely to condone terror. India, as some observers suggest, has been democratic for more than half a century, yet the threat of sectarian violence seems omnipresent. Nor does the evidence support the notion that poverty or illiteracy increases the threat of terror. ${ }^{9}$ If economic deprivation were the culprit, then a century or two ago most societies around the world should have supported terrorist activity, because they were generally worse off (in terms of diet, health care, leisure time, and material wealth) than most societies are today. In addition, it is perhaps noteworthy that fifteen of the nineteen hijackers who struck at the World Trade Center and the Penta-

4. Crenshaw, "The Causes of Terrorism," p. 116.

5. Huntington, "The Age of Muslim Wars," p. 48.

6. Larry Diamond, as cited in Thomas L. Friedman, "The Free-Speech Bind," New York Times, Mach 27, 2002, p. A23.

7. Kenneth N. Waltz, Theory of International Politics (New York: McGraw-Hill, 1979).

8. Larry Diamond, "Introduction: In Search of Consolidation," in Diamond, Marc F. Plattner, Yunhan Chu, and Hung-mao Tien, eds., Consolidating the Third Wave Democracies (Baltimore, Md.: Johns Hopkins University Press, 1997), pp. xiii-xlvii.

9. Krueger and Maleckova, "The Economics and the Education of Suicide Bombers." 
gon on September 11, 2001, were from Saudi Arabia, one of the richest countries in the world. Most of them were highly educated and appeared to have had ample opportunities for building materially rewarding lives.

These facts suggest that rational explanations for the social origins and support of terrorism are inadequate. The September 11 hijackers were motivated by something deeper-something that fundamentally distinguished them from their victims. Put simply, terrorists and their supporters do not think like their victims. From the cultural perspective, terrorists are not merely engaged in a rational strategy of the weak. Rather there is something about ingrained habits and historical traditions that renders terrorism a socially acceptable method for addressing grievances in some societies, but not others. ${ }^{10}$ When such traditions are combined with social, economic, or political grievances, individuals can be "socialized into violence from early childhood," particularly when they experience violence in their formative years. ${ }^{11}$

From a cultural perspective, the creation of a political strategy to combat terror must begin with an examination of terrorists' values and beliefs. What motivates them? What values do they claim justify their actions? Because all the September 11 hijackers were from Islamic countries, and all seemed to express religious motivations, the cultural approach would suggest that there is something inherent in Islamic beliefs and values that yields the social approval of terror. For instance, some observers argue that because the Koran offers instructions "for even the minutiae of everyday life," Islamic culture has tremendous difficulty dealing with change and lacks "a tradition of self-criticism." As a result, some analysts suggest that Muslims tend to be "defensive and insecure"; they are also likely to blame bad news on "exterior, malevolent powers."12

Like rational theories, cultural theories that seek to explain terrorism's origins and base of support have significant weaknesses. For instance, traditional cultural mores are a constant, not a variable, and thus cultural explanations cannot sufficiently account for variation in levels of social support for terror across time and place. More specifically, Islamic values and beliefs cannot explain why the Muslim world did not produce suicidal mass murderers in, for instance, the 1950s, or why millions of Muslims around the world joined others in expressing shock and horror at the events of September 11. Further,

10. Crenshaw, “The Causes of Terrorism," p. 115.

11. Martha Crenshaw, "Thoughts on Relating Terrorism to Historical Contexts," in Crenshaw, ed., Terrorism in Context (University Park: Pennsylvania State University Press, 1992), p. 74.

12. Hume Horan, "Those Young Arab Muslims and Us," Middle East Quarterly, Vol. 9, No. 4 (Fall 2002), pp. 53-54. 
the social support of terror has a tradition in non-Islamic societies (e.g., Catholics and Protestants in Northern Ireland), demonstrating that Muslim culture alone does not sufficiently explain this phenomenon.

Rational approaches have an advantage over cultural approaches because they focus on observable circumstances-poverty, economic inequality, illiteracy, and lack of democracy - that allow scholars to predict when and where social support for terror is likely to emerge. Explanations linking poverty and its related conditions with terror, however, are nebulous. Cultural approaches have an advantage over rational approaches because they are based on the seemingly apparent fact that those who engage in or support suicidal mass murder do not think like people in out-groups (in this case, people in the United States and the rest of the Western world). None of these approaches, however, helps scholars to predict-and thus expose and eradicate-the kinds of values and beliefs that support terror.

To grasp the origins of socially approved terror, scholars need an approach that combines the rationalist identification of observable circumstances with the culturalist emphasis on learning why people think and act as they do. In short, scholars must be able to predict when and where the use of indiscriminate violence against out-groups is likely to be socially approved and when and where it is not. Only then can potential terrorist targets devise a political strategy for eliminating this growing menace.

\section{The Rise of Market Civilization}

Many scholars of politics have suggested that there is a growing need to be able to predict variation in peoples' values and beliefs, ${ }^{13}$ a need illustrated most dramatically by the September 11 terrorist attacks. In this view, political scientists do not have to start from scratch: Anthropologists, economic historians, and sociologists have been at this task for years. Anthropologists have long sought to explain the relationship between economic conditions and values and beliefs; ${ }^{14}$ economic historians have for years linked certain economic conditions with particular sets of values and beliefs, identifying at least two primary kinds of socioeconomic integration in history-clientalism and mar-

13. Robert O. Keohane, "Governance in a Partially Globalized World," American Political Science Review, Vol. 95, No. 1 (March 2001), pp. 1-15; and Alexander Wendt, Social Theory of International Politics (Cambridge: Cambridge University Press, 1999).

14. See Marvin Harris, Cultural Materialism: The Struggle for a Science of Culture (Walnut Creek, Calif.: AltaMira Press, 2001 [1979]); and Maxine L. Margolis, "Introduction to the Updated Edition," in Marvin Harris, The Rise of Anthropological Theory: A History of Theories of Culture, updated ed. (Walnut Creek, Calif.: AltaMira Press, 2001), pp. vii-xiii. 
kets; ${ }^{15}$ and sociologists have documented the social implications of clientalist exchange. ${ }^{16}$

In clientalist economies, the obligations of cooperating parties are implied (rather than made explicit) and take the form of reciprocity, or gift giving. Exchange occurs through the giving of gifts, which reinforces a sense of trust and enduring obligation among the parties. Enforcement of obligations comes with the threat of punishment: Violations of trust lead to severed relationships. Clientalist economies can be complex; ${ }^{17}$ and with specialization, patrons emerge who have more to give than others, creating a surplus of obligations accompanied by increased influence. Because reciprocal obligations are only implied and are socially enforced, patrons rather than states regulate economic cooperation. Examples of clientalist socioeconomies include feudal Europe, and in the contemporary period, mafias and the complex systems of patronage that characterize the politics of redistribution in most developing countries. ${ }^{18}$

Because economic relations are enduring, clientalist economies are based on explicit social linkages, such as kinship and ethnicity. These linkages render ingroups more important than out-groups, making clientalist communities more inward looking than market communities in terms of identity, values, and beliefs. Clientalist communities are also organized hierarchically: Patrons, such as lords, dons, and uncles, receive gifts from clients as expressions of loyalty in exchange for life-long protection. ${ }^{19}$

In market economies, in contrast, the mutual obligations of cooperating parties are made explicit in the form of contracts. The quid pro quo nature of the

15. A third mode of integration, sharing, is common among hunting and gathering societies, but is not discussed here because it has not been a prominent mode of exchange in any state. See Janet $\mathrm{L}$. Abu-Lughod, Before European Hegemony: The World System, A.D. 1250-1350 (New York: Oxford University Press, 1989); Karl Polanyi, The Great Transformation: The Political and Economic Origins of Our Time (Boston: Beacon, 1957 [1944]); Marshall D. Sahlins, Stone Age Economics (Hawthorne: Aldine de Gruyter, 1972); and David W. Tandy and Walter C. Neale, "Karl Polanyi's Distinctive Approach to Social Analysis and the Case of Ancient Greece: Ideas, Criticisms, Consequences," in Colin A.M. Duncan and Tandy, eds., From Political Economy to Anthropology: Situating Economic Life in Past Societies (London: Black Rose, 1994), pp. 19-20.

16. See, for instance, Marcel Mauss, The Gift: The Form and Reason for Exchange in Archaic Societies (New York: W.W. Norton, 2000 [1924]).

17. Polanyi, The Great Transformation, pp. 49-50.

18. See S.N. Eisenstadt and René Lemarchand, Political Clientalism: Patronage and Development (Thousand Oaks, Calif.: Sage, 1981); and Luis Roniger and Aype Günep-Ayata, eds., Democracy, Clientelism, and Civil Society (Boulder, Colo.: Lynne Rienner, 1994).

19. For further discussion of the rules and norms of gift exchange, see Christopher A. Gregory, Gifts and Commodities (San Diego, Calif.: Academic Press, 1983); and Monica Prasad, "The Morality of Market Exchange: Love, Money, and Contractual Justice," Sociological Perspectives, Vol. 42, No. 2 (Summer 1999), pp. 181-214. 
cooperation implies no obligation among the parties beyond that expressed in the contract. Unlike in clientalist economies, therefore, in market economies, strangers and even enemies can cooperate in prescribed ways. ${ }^{20}$ Because contracts cannot be negotiated without explicit assertions of self-interest, their extensive use renders such assertions socially approved. Moreover, a contract imposes an equitable relationship on the parties. ${ }^{21}$ The implications of this are profound: The norm of cooperating with strangers on the basis of legal equality is the logical prerequisite for respecting the rule of common law. Because contractual obligations are explicit, a state can enforce them, and a market economy can emerge if a state is willing and able to enforce contracts with impartiality. In these ways, markets develop and the liberal values of individualism, universalism, tolerance, and equity emerge concurrently with the rule of common law and democratic governance. ${ }^{22}$ Examples of market economies include classical Athens and, in the contemporary period, Sweden and the United States. $^{23}$

The market economy and its liberal belief system also account for the rise of science over faith-based forms of knowledge. Science is anchored in the notion that (1) some facts are universal (universalism), (2) any person can challenge another's assertions of fact, including those of his or her leader (freedom and equity), and (3) truth is sought through the competition of ideas (tolerance). The opposite of science is truth determined by an authority sanctioned by loyalty and faith-the norm in clientalism.

All societies have some combination of clientalist and market exchange. For markets to prevail, however-for a majority of people to engage regularly in making contracts-a complex division of labor associated with economic development is necessary. At lower levels of development and thus incomes, individuals engage in fewer exchanges, and the few big-ticket exchanges that do

20. In this way, the initial emergence of market norms allows for increased specialization and thus greater economic production, which in turn can stimulate a mutually reinforcing cycle of marketintegrated growth. See Michael Mousseau, "Market Prosperity, Democratic Consolidation, and Democratic Peace," Journal of Conflict Resolution, Vol. 44, No. 4 (August 2000), p. 478.

21. William J. Booth, "On the Idea of the Moral Economy," American Political Science Review, Vol. 88, No. 3 (September 1994), pp. 653-667; and Ronald Inglehart, Culture Shift in Advanced Industrial Society (Princeton, N.J.: Princeton University Press, 1990), p. 46.

22. For further discussion of this process, see Mousseau, "Market Prosperity, Democratic Consolidation, and Democratic Peace"; and Michael Mousseau, "Globalization, Markets, and Democracy: An Anthropological Linkage," in Mehdi Mozaffari, ed., Globalization and Civilizations (London: Routledge, 2002), pp. 97-124.

23. Rondo Cameron, A Concise Economic History of the World: From Paleolithic Times to the Present, 3d ed. (New York: Oxford University Press, 1997), pp. 32-35. 
occur-such as getting a job, buying a home, or purchasing expensive consumer goods-are less likely to be mediated by the market (with price determined by supply and demand): More often than not, these will be seen as exchanges of gifts among members of an in-group (with price determined by privileged discount). As a result, developing countries tend to have political cultures characterized by intergroup conflict (deep in-group/out-group feelings), less respect for individual freedom, stronger religious beliefs, greater respect for loyalty and hierarchy than for the rule of law, and extensive informal patronage networks (known for, among other things, high levels of corruption). ${ }^{24}$

Sociologists and economic historians have documented the association of gift giving and contracting norms with, respectively, collectivist and individualist value orientations. ${ }^{25}$ Anthropologists and archaeologists have long considered economic conditions to be a leading influence on cultural mores and institutional structures. ${ }^{26}$ Rational choice theorists and others acknowledge that values affect political behavior ${ }^{27}$; and most agree that, for stability, democracy requires a liberal political culture. ${ }^{28}$ The chain of causation is well established: The evidence linking economic development with liberal values is so overwhelming that the proposition has no serious detractors, ${ }^{29}$ nor does the

24. Mousseau, "Market Prosperity, Democratic Consolidation, and Democratic Peace"; and Mousseau, "Globalization, Markets, and Democracy."

25. Abu-Lughod, Before European Hegemony; Fernand Braudel, Afterthoughts on Material Civilization and Capitalism, trans. Patricia Ranum (Baltimore, Md.: Johns Hopkins University Press, 1979), p. 63; Emile Durkheim, The Division of Labour in Society (Basingstoke, U.K.: Macmillan, 1984 [1893]); Polanyi, The Great Transformation; and Tandy and Neale, "Karl Polanyi's Distinctive Approach." 26. Harris, Cultural Materialism; and Margolis, "Introduction to the Updated Edition."

27. Keohane, "Governance in a Partially Globalized World"; Margaret Levi, Consent, Dissent, and Patriotism (Cambridge: Cambridge University Press, 1997); James D. Morrow, Game Theory for Political Scientists (Princeton, N.J.: Princeton University Press, 1994); Elinor Ostrom, Governing the Commons: The Evolution of Institutions for Collective Action (New York: Cambridge University Press, 1990); and Tom R. Tyler, Why People Obey the Law (New Haven, Conn.: Yale University Press, 1990). 28. Gabriel A. Almond and Sidney Verba, The Civic Culture: Political Attitudes and Democracy in Five Nations (Princeton, N.J.: Princeton University Press, 1963); Robert Alan Dahl, Democracy and Its Critics (New Haven, Conn.: Yale University Press, 1989); Samuel P. Huntington, "Will More Countries Become Democratic?" Political Science Quarterly, Vol. 99, No. 2 (Summer 1984), pp. 193-218; and Seymour Martin Lipset, "Some Social Requisites of Democracy: Economic Development and Political Legitimacy," American Political Science Review, Vol. 53, No. 1 (March 1959), pp. 69-105.

29. Braudel, Afterthoughts on Material Civilization and Capitalism; Geert Hofstede, Culture's Consequences: Comparing Values, Behaviors, Institutions, and Organizations across Nations, $2 \mathrm{~d}$ ed. (Thousand Oaks, Calif.: Sage, 2001 [1980]); and Ronald Inglehart and Wayne E. Baker, "Modernization, Cultural Change, and the Persistence of Traditional Values," American Sociological Review, Vol. 65, No. 1 (February 2000), pp. 19-52. 
stabilizing impact of development on democracy. ${ }^{30}$ Indeed virtually every economically developed democracy in history has been a market democracy.

Although the disciplines of anthropology, economics, political science, and sociology have all addressed different aspects of the relationship between market economies and society, none has examined this relationship in its entirety. Anthropologists and archaeologists typically link cultural mores not to modes of exchange but to environmental conditions, ${ }^{31}$ some economists have argued that the social implications of markets invalidate the core assumptions of neoclassical liberalism, ${ }^{32}$ and others have addressed the role of social capital in economic growth; ${ }^{33}$ political scientists have focused on how development, not the market economy, stabilizes democracy; ${ }^{34}$ and sociologists have highlighted the social, but apparently not the political, consequences of gift exchange. ${ }^{35}$

Findings from these four disciplines help to explain the rise of market civilization and its supremacy in the contemporary era. Surveys and other works have established that the inhabitants of high-income countries-most of which have developed market economies-share common liberal values; ${ }^{36}$ other studies confirm that elected leaders seek to promote domestic values in making foreign policy. ${ }^{37}$ If median voters in market democracies have liberal values

30. Ross E. Burkhart and Michael S. Lewis-Beck, "Comparative Democracy: The Economic Development Thesis," American Political Science Review, Vol. 88, No. 4 (December 1994), pp. 111-131; and Adam Przeworski and Fernando Limongi, "Modernization: Theories and Facts," World Politics, Vol. 49, No. 2 (January 1997), pp. 155-183.

31. See, for example, R. Brian Ferguson, Yanomami Warfare: A Political History (Sante Fe, N.M.: School of American Research Press, 1995).

32. See Polanyi, The Great Transformation.

33. Stephen Knack and Philip Keefer, "Does Social Capital Have an Economic Payoff? A Crosscountry Investigation," Quarterly Journal of Economics, Vol. 112, No. 4 (November 1997), pp. 12511288.

34. Lipset, "Some Social Requisites of Democracy"; and Dietrich Rueschemeyer, Evelyne Huber Stephens, and John D. Stephens, Capitalist Development and Democracy (Chicago: University of Chicago Press, 1992).

35. Mauss, The Gift; and Prasad, "The Morality of Market Exchange."

36. Braudel, Afterthoughts on Material Civilization and Capitalism; Yun-han $\mathrm{Chu}, \mathrm{Fu} \mathrm{Hu}$, and Chungin Moon, "South Korea and Taiwan: The International Context," in Diamond et al., Consolidating the Third Wave of Democracies, pp. 267-294; Hofstede, Culture's Consequences; and Inglehart and Baker, "Modernization, Cultural Change, and the Persistence of Traditional Values."

37. George C. Edwards III and B. Dan Wood, "Who Influences Whom? The President, Congress, and the Media," American Political Science Review, Vol. 93, No. 2 (June 1999), pp. 327-345; Ronald H. Hinckley, Peoples, Polls, and Policymakers: American Public Opinion and National Security (New York: Lexington, 1992); Jeffrey W. Knopf, "How Rational Is the 'Rational Public'? Evidence from U.S. Public Opinion on Military Spending," Journal of Conflict Resolution, Vol. 42, No. 5 (October 1998), 
and median voters in all other types of democracies do not, then only the elected leaders of the market democracies are likely to have liberal values and a political incentive to pursue a liberal foreign policy course. In this way, the common liberal values of their electorates constrain leaders of market democracies (but not leaders of other types of democracies) to pursue common aims in foreign affairs: for instance, to respect and promote international law, human rights, and an equitable global order.

Proponents of the democratic peace note the apparent dearth of militarized conflict among democratic nations. ${ }^{38}$ It now appears, however, that this peace is limited to the advanced market democracies. ${ }^{39}$ Democratic dyads where at least one state lacked a developed market economy and that have had a history of militarized confrontation include India and Pakistan, Greece and Turkey, and Ecuador and Peru. Moreover, market democracies-but not other types of democracies - tend to cooperate with each other against other states. ${ }^{40}$ They also tend to express common positions in the United Nations General Assembly. ${ }^{41}$ Of course, leaders of market democracies do not agree on everything, but they do agree on the fundamentals: how the world should be organizedpolitically, economically, and socially-and what constitutes proper governmental behavior both internally and externally. When differences surface among market democracies, the discourse is bounded by mutual respect for state rights (equity) and the primacy of international law-just as the domestic political behavior of the governments of these democracies is culturally

pp. 544-571; Timothy J. McKeown, "The Cuban Missile Crisis and Politics as Usual," Journal of Politics, Vol. 62, No. 1 (February 2000), pp. 70-87; Benjamin I. Page and Robert Y. Shapiro, The Rational Public: Fifty Years of Trends in Americans' Policy Preferences (Chicago: University of Chicago Press, 1992); and Douglas A. Van Belle and Steven W. Hook, "Greasing the Squeaky Wheel: News Media Coverage and U.S. Development Aid, 1977-1992," International Interactions, Vol. 26, No. 3 (JulySeptember 2000), pp. 321-346.

38. Stuart A. Bremer, "Dangerous Dyads: Conditions Affecting the Likelihood of Interstate War, 1816-1965," Journal of Conflict Resolution, Vol. 36, No. 2 (June 1992), pp. 309-341; Bruce M. Russett, Grasping the Democratic Peace: Principles for a Post-Cold War World (Princeton, N.J.: Princeton University Press, 1993); and James Lee Ray, Democracy and International Conflict: An Evaluation of the Democratic Peace Proposition (Columbia: University of South Carolina Press, 1995).

39. Mousseau, "Market Prosperity, Democratic Consolidation, and Democratic Peace"; and Michael Mousseau, Håvard Hegre, and John R. Oneal, "How the Wealth of Nations Conditions the Liberal Peace," European Journal of International Relations, Vol. 9, No. 4 (June 2003), in press.

40. Michael Mousseau, "An Economic Limitation to the Zone of Democratic Peace and Cooperation" International Interactions, Vol. 28, No. 2 (April-June 2002), pp. 137-164.

41. Michael Mousseau, "The Nexus of Market Society, Liberal Preferences, and Democratic Peace: Interdisciplinary Theory and Evidence," International Studies Quarterly, Vol. 47, No. 3 (September 2003), in press. 
bounded by respect for individual rights and the primacy of democratic law. There is, in short, a market civilization.

\section{The Clash against Market Civilization}

Few if any states have predominantly clientalist economies. Most economies are heavily integrated with the market (market democracies) or include some mixture of clientalism and markets (developing countries). Although in many developing countries contracts are officially enforced and regulated, in-group linkages can diminish impartiality. In addition, because clientalist exchange is informal, it lies beyond the regulatory capacity of the state. In this mixed economy, the clash of clientalist and market cultures can lead to illiberal and unstable democracy, military dictatorship, state failure, sectarian violence, or some combination thereof-and bitter anti-Americanism.

In clientalist societies, cooperation occurs with the exchange of gifts, and trust is based on life-long friendships within in-groups. In market societies, loyalty to the in-group is downgraded, as cooperation with strangers is encouraged; trust is based not on friendship but on the perceived universal principle of the sanctity of contractual exchange. Individuals from market cultures thus seek out cooperation universally. From the clientalist perspective, however, those with market values are from out-groups and thus are untrustworthy. Moreover, by expressing self-interest, individuals with market values are viewed as selfish; they appear to have no culture and are seemingly interested in little beyond the crude pursuit of material gain.

Cultures change slowly; so when endogenous factors cause a rise in contractual exchange, a clientalist society's economic norms diverge from prevailing cultural values and beliefs. When this happens, individuals with deeply embedded clientalist values have difficulty grasping new market norms; they perceive that those who are driven by self-interest not only lack strong social ties but have no values at all. This perception is partly true: A society that undergoes economic change may experience a period when there is no common culture, as clientalist linkages break down before market values emerge.

During this period of social anarchy, a zero-sum culture may emerge in which strangers pursue their interests without any regard for shared valuesmarket or clientalist. This explains the circumstances in many developingworld societies today: that is, widespread disrespect for the rule of law (everyone wants the law to apply to someone else); social chaos, as many act without 
regard for others (e.g., unwillingness to wait in line or obey rules); and the apparent lack of empathy for anyone outside one's in-groups (family, friends, and coworkers). ${ }^{42}$ From the market perspective, these conditions seem uncivil and are often assumed to be a consequence of local indigenous culture (i.e., a "supposed" function of Arab culture, Asian culture, and so on). Academics from market cultures have assumed that what people in these countries need is more education, ${ }^{43}$ a democratic form of government, ${ }^{44}$ or time to develop. ${ }^{45}$ As I have sought to show, however, this behavior may not be associated with any particular indigenous culture, form of government, or inherent backwardness. Rather, it may reflect the breakdown of clientalist linkages in economies that, facing severe and persistent economic shocks, have not replaced their clientalist values with market values.

Although great differences remain across the developing world, traditional clientalist protections tend to be strongest in rural areas. Urban communities, on the other hand, are more likely to be in flux, with new patron-client networks (e.g., political parties, unions, and mafias) increasingly replacing traditional patron-client networks (e.g., clans and villages). Strangers in these communities, lacking in both empathy and mutual respect, frequently interact on the basis of few if any common values and beliefs. Meanwhile, in-groups compete over state resources in a zero-sum way-with winners taking all. This helps to explain (1) the high frequency of political violence in developing countries; (2) why democratic institutions in such countries seem to do so poorly in producing public goods, such as roads and security; and (3) why the absence of a strong state often results in chronic instability, civil conflict, and in some cases state failure.

No economic transition can erase a society's collective history or memory, nor can it eliminate the role of external influences, ethnic diversity, and historical animosity among competing factions. Moreover, the breakdown of traditional clientalist linkages is not the only source of social anarchy in developing countries: War and state failure can also be factors, as witnessed in Afghanistan and Somalia, where both rural and urban areas remain in tremendous

42. As documented by Hofstede, Culture's Consequences.

43. Daniel Lerner, The Passing of Traditional Society: Modernizing in the Middle East (New York: Free Press, 1958); and Alex Inkeles and David Smith, Becoming Modern: Individual Change in Six Developing Countries (Cambridge, Mass.: Harvard University Press, 1974).

44. Diamond, "Introduction: In Search of Consolidation."

45. Talcott Parsons, "Evolutionary Universals in Society," American Sociological Review, Vol. 29, No. 3 (June 1964), pp. 339-357. 
flux. Likewise, mineral wealth in a developing economy with weak market norms probably works to reinforce the influence of traditional clientalist ingroups, as patrons spread their riches in return for pledges of loyalty. For the majority of countries without mineral wealth, however, the mire of underdevelopment and economic displacement has meant a rise in social anarchy and civil insecurity.

For many individuals living in this rough-and-tumble Hobbesian world, the new zero-sum culture has a thoroughly Western or American character, as seen on television, in movies, and in other forms of popular culture exported from Europe and the United States. Lacking market values and beliefs, millions of people in developing countries believe that the breakdown of traditional clientalist relationships and the emergence of zero-sum anarchy are results of a growing Westernization or Americanization of their societies, and they deeply resent it. Moreover, a society with clientalist values and beliefs but with fading protections from in-groups is extremely vulnerable to any in-group system that promises to put an end to its deep sense of insecurity. This explains the allure of alternative value systems in developing countries that support ethnic sectarianism, extreme nationalism, or various types of religious fundamentalism.

A brief examination of the impact of economic change in the contemporary period confirms this view. Contractual exchange in the modern period began in northwestern Europe in the $1450 \mathrm{~s},{ }^{46}$ precipitating for the next 200 years the social and institutional changes brought about during the Protestant Reformation. For three centuries after that, many states in Europe (e.g., England and Holland) began to develop market economies-by enforcing contracts, subsidizing private enterprise, and breaking up clientalist linkages. ${ }^{47}$ Only in the twentieth century, however, did the majority of Europeans possess the resources to engage regularly in contractual exchange. The combination of nineteenth-century industrialization and mass migration to the United States greatly increased the demand for, and thus the wages of, labor in Europe. As a result, Europe's majority, once clients in a clientalist world, became buyers in a new market world. ${ }^{48}$

The political repercussions of this socioeconomic transition were vast: Euro-

46. Braudel, Afterthoughts on Material Civilization and Capitalism, p. 24.

47. As documented by Polanyi, The Great Transformation.

48. See Simona Piattoni, ed., Clientelism, Interests, and Democratic Representation: The European Experience in Historical and Comparative Perspective (Cambridge: Cambridge University Press, 2001). 
pean peasants gave up their way of life-including traditional in-group protection-only to arrive in cities in the midst of rapid economic change and seemingly devoid of common values and beliefs. Like their counterparts in the nineteenth century, today's migrants confront a bewildering array of zero-sum conditions and Hobbesian anarchy. In both cases, the refugees created by these socioeconomic disruptions sought economic and political protection by joining new forms of clientalist in-groups; and in both cases, they seem to have perceived the rise of market exchange as lacking any redeeming social value. The consequences were the same in both cases: Just as many Europeans in the last century were drawn to clientalist in-groups that championed antimarket (i.e., socialist, communist, or fascist) values, many of today's refugees have been pulled toward antimarket socialist, nationalist, or religious political organizations. I say organizations because these clientalist in-groups are not civicoriented political parties: They offer all-encompassing social, economic, and political programs in exchange for absolute loyalty.

In the midst of industrial change, many Europeans joined ethnic sectarian groups, including some that identified European Jewry as the cause of their social anarchy. Frequently, European Jews were merchants and thus tended to behave according to market norms by, among other things, expressing selfinterest through the use of contracts. Faced with the increasing destruction of their traditional clientalist linkages and rising social anarchy, many other Europeans began to equate the proliferation of zero-sum values with Jewish values. Seeking support in socially collapsing societies, some political leaders unleashed antimarket passions by encouraging pogroms against the seemingly "cultureless" (but really just liberal) Jews. One such leader, Adolf Hitler, was himself from a poor migrant section of Vienna-as were many of his followers. While Germany was in the midst of a rapid transition toward a market economy in the 1920s, hyperinflation eliminated the savings of the nascent middle class. This caused a widespread loss of faith in contracts, a revival of clientalist values, and an antimarket fury that legitimated the mass murder of outgroups. This explains why the Nazis replaced the failing market with a statedirected economy, and why the Germans (and others) became Hitler's willing executioners." ${ }^{49}$ In fact, across Europe and across time, the strength of antiSemitism seems to correlate negatively, and the stability of democracy positively, with the intensity of the market economy. One indication of this is the

49. Daniel J. Goldhagen, Hitler's Willing Executioners: Ordinary Germans and the Holocaust (New York: Alfred A. Knopf, 1996). 
availability of jobs that offer a living wage. Significantly, just one generation after the U.S. imposition and subsidization of a market economy in West Germany following the end of World War II, West Germans were well on their way toward developing a liberal political culture. ${ }^{50}$

Europe's transition to a market economy in the nineteenth and early twentieth centuries led to the rise of antimarket socialist, communist, and fascist movements as well as sectarian terror. Similarly, the transition toward a market economy in many contemporary developing countries is associated with antimarket socialist, ethnofascist, hypernationalist, and religious fundamentalist movements-as well as sectarian terror. Examples include the Marxist guerrillas in Latin America, such as the FARC in Colombia and the Shining Path in Peru; increasing ethnic identification, and popularity of hypernationalist political parties, in parts of Russia and Turkey; and the rise of religious fundamentalism in India and much of the Islamic world. Although the character of these movements varies, the catalyst is the same: bitter opposition to market (liberal) values. Herein lays the source of today's widespread anti-Americanism and anti-Westernism: The liberal way of life in the United States and the rest of the West-its cold materialism, from the clientalist perspective-is being broadcast to homes around the world, many of which are transitioning to market economies. In this way, just as the Jews symbolized emerging market norms in Europe a century ago, today, with modern technology, American and Western culture symbolizes the dreaded market norms linked with globalization.

\section{The Resort to Terror}

Those on the lowest rung of the economic ladder are the most vulnerable to the negative consequences associated with globalization. Those with the most to lose, however, are patrons and their lieutenants who hold privileged positions in the old clientalist hierarchies. This is why leaders of terrorist organizations frequently come from privileged backgrounds. To maintain the clientalist structure that carries with it higher social status, these leaders seek to rally their client base by appealing to some antimarket ideology. Because it is in a

50. See Ronald Inglehart, Modernization and Postmodernization: Cultural, Economic, and Political Change in Forty-three Societies (Princeton, N.J.: Princeton University Press, 1997), p. 175. Of course, the socioeconomic transition cannot explain the long history of anti-Semitism in Europe, much of which predates the rise of markets. 
client's interest to have a powerful patron, leaders attract and maintain followers by demonstrations of strength. In this way, the mass murder of Westerners serves two purposes: It reflects the leader's power, and it taps into widespread antimarket fury.

Islam itself is not responsible for the social approval of terror. Patrons fearing the loss of their privileged status-such as Osama bin Laden-find an antimarket ideology useful to attract followers. They manipulate Islam to serve their own ends, just like their counterparts in Europe did a century ago by contorting Christianity to justify terror and mass murder. ${ }^{51}$ In fact, Islam emerged in Mecca, the center of sixth-century Mediterranean and South Asian trade, and the Koran stress the market values of universalism, equity, contractual exchange, and a degree of tolerance toward outsiders (non-Muslims). ${ }^{52}$ The market economy in this region declined before market norms-and liberal culture-intensified and expanded throughout the Islamic world, but the liberal origins of Islam demonstrate that religion can be interpreted, and manipulated, to suit anyone's purposes.

In societies steeped in market values, it is difficult to comprehend how anyone can engage in the mass murder of out-groups, or how anyone can support it. Individuals with market values believe that each person is responsible only for his or her actions. Just as those who are not parties to contracts cannot be made obligated to them, individuals cannot be assumed to be responsible for any and all behavior of other members of their apparent in-group. It therefore seems absurd to blame individuals for the alleged bad behavior of others, and this is the social origin of the presumption of individual innocence in market societies. From the clientalist perspective, in contrast, no one is innocent: Individuals share responsibility for the actions of others within the in-group; if followers do not support their leaders, then they are betraying the entire ingroup. From the clientalist perspective, all in-group members are privileged and all out-group members are enemies or, at best, outsiders unworthy of em-

51. Although Osama bin Laden is from Saudi Arabia, I do not contend that Saudi Arabia has an emerging market economy. On the contrary, its oil wealth has served to reinforce its clientalist linkages, as patron sheiks spread their wealth in return for loyalty. With globalization and satellite television, however, patrons have reason to feel threatened by the perceived omnipresence of zerosum norms and Americanization, a fear that fuels resentment toward the West and, more specifically, the presence of U.S. troops on Saudi soil. Support for al-Qaeda appears in tribal linkages in Saudi Arabia and Yemen, as well as in poor Muslim countries facing the social anarchy of development, such as Egypt, Indonesia, and Pakistan.

52. Ali A. Mazrui, Cultural Forces in World Politics (Portsmouth, N.H.: Heinemann, 1990). 
pathy. A paucity of empathy is necessary for doing harm to, and tolerating the suffering of, all out-group members. This is why international human rights are a concern promoted mostly by market democracies. It is also why widespread social support for both terrorism and sectarian violence frequently arises in developing countries but not in countries with deeply integrated markets. ${ }^{53}$

Clientalist values also lie at the core of the social approval of suicidal mass murder. From the market perspective, all behavior should have some immediate utility for the parties to a contract. It is thus difficult to comprehend the efficacy of suicide. But in cultures where the individual is less important than the group and the absence of science increases devotion to insular beliefs, suicide-under conditions of extreme socioeconomic disruption-may emerge as a socially approved way of expressing ultimate loyalty to the in-group. In this way, cultural insularism, characterized by the absence of a market economy, is a necessary condition for the social approval of suicidal mass murder and sectarian violence.

Cultural insularism combined with a particular grievance-such as the negative consequences associated with globalization-can create a deadly mix for Americans and other Westerners. Although latent anti-Americanism and antiWesternism exist throughout much of the developing world, these are most likely to rise to the surface during economic crises-when nascent middle classes lose their status and turn against emerging liberal values. This is what is happening, for example, in Indonesia where the recent collapse of the local currency has eliminated the savings of the middle class, just as hyperinflation devastated the savings of Germany's middle class seventy-five years ago. Recent terrorist acts against Indonesian Christians (as symbols of the West) and Westerners directly (the November 2002 bombing of a disco in Bali) are reminiscent of Germany's middle class turning against those it identified with market values, such as European Jews and the West. The West, in this sense, means market civilization.

53. The closest possible exceptions that I am aware of are the socially approved lynchings of African Americans by white Southerners in the 1920s and 1930s and the sectarian murders during the Troubles in Northern Ireland. In my view, however, the economies of neither the Southern states in the United States nor Northern Ireland were primarily integrated with contracts-and this helps to explain the sectarian terror. Of course, this is an empirical issue that could be explored in future research. 


\section{The Eradication of Terror}

Terrorism has both expressed and underlying causes. Expressed causes are those that terrorists assert themselves. Emic analysis, in which subjects are asked to explain why they behave as they do, identifies expressed causes. It does not explain, however, why some acts inflame passions while others go unnoticed. For instance, hundreds have died in recent violence between Hindus and Muslims in India, including many Muslims. Yet these killings have elicited "an emotionally muted headline in the Arab media." When Israelis kill Muslims, however, as has occurred in the most recent round of Middle East violence, "it inflames the entire Muslim world." ${ }^{54}$ To understand these different responses, scholars must engage not only in emic but also in etic analysis: They need to be able to interpret the behavior of their subjects. Why do so many Indonesians, for instance, empathize with the plight of the Palestinians but seem to express little outrage over the deaths of Indian Muslims? The reason is Israel's identification with the United States and emerging markets. Although identification with Islam may be an expressed cause of this rage, the underlying cause is not Islam but rather a deeply embedded antimarket and thus antiAmerican passion-a fury that extends beyond the Islamic world and whose origins are not understood even by those espousing hatred for the West.

This sense of rage against market civilization and its shared liberal values and beliefs - a rage that can be inflamed with the addition of any immediate cause-lies just beneath the surface in many developing countries. This is not to say that all or even the majority of people living in the developing world share this wrath, but that the potential for a clash is ever-present. Once policymakers understand this, they can begin to develop the kinds of political strategies needed to eliminate the terrorist threat.

Since the terrorist attacks of September 11, three myths have emerged regarding the direction that these strategies should take; all three threaten to derail efforts to eradicate terror. The first myth is that to win the hearts and minds of people around the world in the struggle against terror, the United States must do more to signal its friendly intentions-for instance, by increasing economic aid and explaining U.S. policies more clearly. ${ }^{55}$ This view is mistaken.

54. Thomas L. Friedman, "The Core of Muslim Rage," New York Times, March 6, 2002, p. A21. 55. Articles representing influential American think tanks that take this view include Daalder and Lindsay, "Nasty, Brutish, and Long"; and Peter G. Peterson, "Diplomacy and the War on Terrorism," Foreign Affairs, Vol. 81, No. 5 (September-October 2002), pp. 74-96. 
The rage against the United States as the leading symbol of the West is so deeply embedded in some societies that many will interpret whatever the United States does with malign intent. If the United States offers to increase economic aid, it is seen as imperialist; if it does not, it is neglectful. If the United States intervenes to protect Muslims, as it did in the 1999 Kosovo conflict, critics will rail against U.S. "imperialism" (there must be oil there) or, at best, charge that the United States intentionally delayed the intervention because Americans really hate Muslims. Consider that in clientalist cultures the notion of science-universal truth-is incomprehensible. ${ }^{56}$ For this reason, even many educated people in the developing world believe in such nonsense as the notion that 4,000 Jews were warned not to go to work at the World Trade Center on September 11: ${ }^{57}$ These people believe what they want to believe, regardless of the evidence before them. In fact, for those enraged against the United States for its perceived zero-sum values, friendly acts will have no positive effect. The implication of this is liberating: In terms of underlying causes, the United States need not worry about how societies that produce or harbor terrorists perceive its actions in the war against terrorism. Given that whatever the United States (and other market democracies) do will be interpreted as malevolent, they may as well behave as they see fit.

The second myth associated with September 11 is that terror arises in the absence of democracy, ${ }^{58}$ and therefore the United States should push harder for democratic change in developing countries. This view is also flawed. Stable democracies emerge when people want them to, when they share the liberal values and beliefs that prevail in market economies. It is understandable that scholars, policymakers, and pundits in market democracies value democracy and consider it a cure-all against evil: In market civilization, democratic institutions are a deeply embedded value. There is little evidence, however, that democracy causes liberal values. History shows that democracy without lib-

56. The notion of science should not be confused with the use of advanced technology or education. Science is a process of discovery that assumes that some facts are universal, anyone can challenge another's assertions of fact, and truth is sought through the free competition of ideas. One can be taught the discoveries of advanced physics but still have no concept of challenging assertions of fact scientifically. This is why communist and developing nations can import and modify advanced technology, but the market democracies will always be in the avant-garde of developing knowledge.

57. Thomas L. Friedman, "Global Village Idiocy," New York Times, May 12, 2002, sec. 4, p. 15; see also Horan, "Those Young Arab Muslims and Us," p. 54.

58. For example, Crenshaw, "The Causes of Terrorism"; Friedman, "The Free-Speech Bind"; Huntington, "The Age of Muslim Wars"; and Nicholas D. Kristof, "What Is Democracy Anyway?" New York Times, May 3, 2002, p. A23. 
eral values results in illiberal democracy and the rise to power of antidemocratic regimes that frequently display antimarket and clientalist-and therefore terrorist-orientation, such as the Bolsheviks in Russia and the Nazis in Germany.

The third myth to emerge after September 11 is that if people who detest the United States only had greater exposure to American values, their hatred would dissipate. ${ }^{59}$ This view is premised on the assumption that because Americans know they are nice people, others will feel the same way if only they get to know them better. This view is also inaccurate. Anti-American rage is the result of people knowing Americans too well. The problem is that they just do not like what they see, because from the clientalist perspective, American values reflect a degeneration of culture and the ascendance of zero-sum norms. Ironically, the notion that modern culture means no culture is also a common assumption of many academic models of global politics. ${ }^{60}$ As I have deduced from my analysis of the market economy, however, modern culture does possess values - the values of contractual exchange. The task for the United States in the struggle against terrorism then is not to expose more of itself but to counteract the ill effects of too much exposure by more subtly demonstrating the redeeming aspects of market culture.

To win the war against terrorism, the United States and other market democracies must remove the underlying cause of terror: the deeply embedded antimarket rage brought on by the forces of globalization. To do this, the market democracies have only one option: to boost developing countries out of the mire of social anarchy and into market development. Most developing countries cannot make this transition alone, because their leaders are likely to hold clientalist rather than market values and beliefs. Furthermore, maintaining their grasp on power typically involves redistributing state resources among winning coalitions of clientalist in-groups. In this way, current forms of foreign aid may actually reinforce values and beliefs that condone terror, as recipient governments use the aid to pay off supporters and reinforce clientalist linkages. In fact, studies report that much foreign aid pays the salaries of bureaucrats and those working for aid agencies. ${ }^{61}$ Because these jobs are frequently

59. See, for instance, Friedman, "Global Village Idiocy."

60. See, for instance, Bruce Bueno de Mesquita, James D. Morrow, Randolph M. Siverson, and Alastair Smith, "An Institutional Explanation of the Democratic Peace," American Political Science Review, Vol. 93, No. 4 (December 1999), pp. 791-807; and Waltz, Theory of International Politics. 61. See "Dubious Aid," Canada and the World Backgrounder, Vol. 65, No. 6 (May 2000), p. 27. 
obtained through clientalist linkages, current forms of aid can actually promote the very clientalist values that can legitimate the resort to terror.

Because governments of developing countries are unlikely to get out of the mire of social anarchy and into market development themselves, an outside power is needed to act as a sort of Leviathan: to push the governments of target countries to establish the prerequisites of a market economy. These include impartial enforcement of contracts and common law; destruction of clientalist linkages (corruption); subsidization of private enterprises (with fair bidding practices); widespread equitable subsidization of small loans so people can purchase homes or start small businesses; and redistribution to widen the scope of opportunities for market engagement. In the 1980s, Ronald Reagan's administration encouraged cuts in the number of state-owned enterprises in a variety of countries. State ownership of enterprises is not the problem, however: The problem is when state ownership prevents an enterprise from competing fairly in the market. In recent years the International Monetary Fund has begun to enforce rules of equity in banking practices. ${ }^{62}$ For the most part, however, policymakers have placed greater emphasis on balancing budgets, supporting democratization, ${ }^{63}$ and reducing poverty. ${ }^{64}$ It is not deregulated markets, democracy, or an absence of poverty that produces liberal values, however, but rather a market economy. ${ }^{65}$ Thus, to reduce the social support of terror, market democracies should use economic aid as both a means and an incentive for governments in developing countries (1) to create and enforce bodies of common law that are vital to the functioning of a market economy, and (2) to equitably subsidize local private enterprises with the goal of widespread employment. The latter is critical during the transition period: The availability of living-wage jobs in the market alleviates insecurity and prevents antimarket rage.

Given the deep distrust of U.S. motives among the millions living in the social anarchy of underdevelopment, other market democracies must share the burden of pulling them out of this mire. One option would be to create an in-

62. Ajit Singh, "Aid, Conditionality, and Development," Development and Change, Vol. 33, No. 2 (2002), pp. 299-300.

63. James K. Boyce, “Unpacking Aid," Development and Change, Vol. 33, No. 2 (2002), p. 242.

64. Graham Bird, "A Suitable Case for Treatment? Understanding the Ongoing Debate about the IMF," Third World Quarterly, Vol. 22, No. 5 (October 2001), pp. 823-848.

65. A market economy is not a free market. A market economy is one in which the majority of people routinely engage in contractual exchange. Thus a market economy may be highly regulated (e.g., Sweden) and, in theory at least, be publicly owned. A free market, in contrast, refers to a deregulated or partially regulated economy that can coexist with underdevelpment (e.g., Kenya). 
ternational organization with substantial powers to monitor compliance with aid conditions, run by the donor states yet unconstrained by their independent interests. In this way, multilateralism could legitimate the indirect external control of the economies of recipient states during their transitions. Multilateral action would also allow the United States to keep a lower profile and include its allies as partners in the war against terror.

The historical record shows that market democracies easily cooperate and establish legal regimes among themselves. ${ }^{66}$ The European Union and the North Atlantic Treaty Organization are just two of the many regimes that bind these countries together. Although differences do occur, they are mostly at the level of tactics and not over major goals. Sharing preferences and bounded by the logic of contractual exchange, market democracies manage their relationships and resolve their disputes with other market democracies through a combination of mutual respect (equity), common law, and in the absence of law, negotiation and compromise. As German Chancellor Gerhard Schröder described his country's recent rift with the United States, "Between friends, there can be factual differences." ${ }^{67}$ Like West Germany after World War II, developing countries whose market economies are subsidized are likely to one day have market economies, at which time their newly emerged liberal values will reinforce their market-democratic institutions, and there will be no further need of foreign assistance. The social basis of terror against the United States and its allies could thus be eradicated.

\section{Conclusion}

Until now there have been two general approaches to understanding the motivations behind terrorism, one rational and the other cultural. Rational explanations focus on the role of political and economic grievances and assume that certain observable factors associated with poverty such as economic inequality, illiteracy, and lack of democracy cause terror. None of these approaches, however, has established a direct causal link between any of these factors and terror. Nor does there appear to be a correlation between poverty and terror.

Cultural explanations, in contrast, focus not on political or economic conditions but on the notion that the values and beliefs of terrorists and their sup-

66. Mousseau, "An Economic Limitation to the Zone of Democratic Peace and Cooperation." 67. Quoted in Steven Erlanger, "Moves by Germany to Mend Relations Rebuffed by Bush," New York Times, September 24, 2002, p. A1. 
porters are vastly different from those of their targets. Typically, however, these explanations identify indigenous culture as the causal variable, which makes this approach unsuitable for predicting variation in social support for terror within cultures across both time and place. To grasp the origins of terror and why some support it, scholars need an approach that combines the rationalist identification of observable circumstances with the culturalist emphasis on the way people think.

In this article I drew on several generations of research in anthropology, economics, political science, and sociology to show how the values and beliefs that support terror-a lack of empathy for out-groups, an emphasis on community over the individual, and an incomprehension for objective truth and individual innocence-arise from the clientalist economic linkages that are commonplace in many developing countries. In contrast, values that work against terror-individualism, tolerance, equity, and the rule of common lawarise with a market economy. Because all market economies in the contemporary period have been developed economies, there appears to be a link between underdevelopment and terror. As I have argued, however, the real culprit is social anarchy produced by globalization and the difficulties attending the transition to a market economy. Just as millions in the last century turned to antimarket and sectarian values during the rise of market economies in Europe, today millions in the developing world support antimarket and sectarian values reflected in support for ethnofacism, sectarian murder, and fundamentalist religions-anything that offers psychic comfort in the face of volatile social anarchy.

It follows that there is a market civilization based on common liberal values and beliefs, and that this civilization is in conflict with much of the developing world. Direct and expressed causes bring this conflict to the surface at particular times and places. Beneath the surface, however, lies a deeply embedded clash of cultures: market civilization versus the rest. A number of scholars have noted signs of this conflict but have typically identified indigenous culture, not the market economy, as exogenous. ${ }^{68}$ The problem with this view is that it

68. The most prominent argument for this view in recent years appears in Samuel P. Huntington, The Clash of Civilizations and the Remaking of World Order (New York: Simon and Schuster, 1996). For empirical challenges to this thesis, see Errol Anthony Henderson and Richard Tucker, "Clear and Present Strangers: The Clash of Civilizations and International Conflict," International Studies Quarterly, Vol. 45, No. 2 (June 2001), pp. 317-338; and Bruce M. Russett, John R. Oneal, and Michaelene Cox, "Clash of Civilizations, or Realism and Liberalism Déjà Vu? Some Evidence," Journal of Peace Research, Vol. 37, No. 5 (September 2000), pp. 583-609. For Huntington's response to Russett, Oneal, and Cox, see Samuel P. Huntington, "Try Again: A Reply to Russett, Oneal, and Cox," ibid., pp. 609-610. 
assumes that liberal values emerge from Western indigenous culture. Although this view is pervasive ${ }^{69}$ it runs contrary to the historical record. For instance, a generation after Max Weber wrote about the virtues of the Protestant ethic, ${ }^{70}$ millions of Protestants in the West conspired to murder millions of Jews. ${ }^{71}$ The Nazis are just one prominent example of Western barbarism; white Southern Protestants in the United States who participated in lynchings in the early twentieth century are another. To many, it may seem as though liberal values are inherently Western, but this notion rests on a biased selection of the evidence. It ignores cases of Western barbarity. Empirical research across several disciplines demonstrates that it is market development that correlates with liberal values. ${ }^{72}$ Although this conclusion may be unsettling for many scholars of global politics, it offers a better accounting of global history. More important, it carries a liberating implication for progressive leaders in the developing world: The rise of markets and liberal culture will not make a developing country any more Western than the rise of a market economy in England made the British any more Dutch.

Nevertheless, there is nothing in this thesis that argues against other possible sources of anti-Americanism and anti-Westernism. Realists and world systems theorists might focus on the projection of U.S. military power from the core into the periphery as the source of anti-Americanism; liberal institutionalists may focus on what they consider the unilateralist turn that U.S. foreign policy recently seems to have taken. These sources of anti-Americanism, however, exist primarily on the surface and are present mostly in the West and at universities. Antiglobalization protesters within market democracies, for instance, frequently express anti-American and antimarket sentiments. These protesters, however, call for greater global equality-a deeply embedded lib-

69. See, for example, Francis Fukuyama, "The Primacy of Culture," Journal of Democracy, Vol. 6, No. 1 (January 1995), pp. 7-14; and Ronald Inglehart, "The Renaissance of Political Culture," American Political Science Review, Vol. 82, No. 4 (December 1988), pp. 1203-1230.

70. Max Weber, The Protestant Ethic and the Spirit of Capitalism, trans. Talcott Parsons (New York: Charles Scribner's Sons, 1958 [1904-05]).

71. See Goldhagen, Hitler's Willing Executioners.

72. For the observation that a rise in markets liberalizes values, see Braudel, Afterthoughts on Material Civilization and Capitalism. There is extensive cross-national data linking economic development and liberal values, with the overwhelming majority of observed cases of development being cases of market-oriented development. See Hofstede, Culture's Consequences; and Inglehart and Baker, "Modernization, Cultural Change, and the Persistence of Traditional Values." For specific empirical confirmation that it is market development-and not other kinds of development-that promotes liberal values, see Michael Mousseau, "Market Culture and Peace among Nations: It's the Market Democracies That Ally," paper presented at the annual meeting of the American Political Science Association, Boston, Massachusetts, August 26-September 1, 2002. 
eral preference. Although these protesters may also express resentment of the market, they do so for the same reason that many people in developing countries resent the market: They are typically young students with little direct experience in the marketplace. Regardless, such anti-Americanism appears only among a minority of the West, and few would suggest that antiglobalization protesters would support the mass murder of Americans and other Westerners-a preference that requires a radically different set of values than those associated with market democracies.

Once the rise of market civilization and its clash with the rest is understood, political strategies for winning the war against terror can be developed. Just as the United States imposed and subsidized the emergence of market economies in Germany and Japan after World War II-effectively liberalizing their cultures-market democracies today must subsidize the rise of markets in developing countries. This does not mean deregulating their economies, which would do little to inhibit clientalist linkages or encourage trust in contractual exchange. Nor is wealth the source of liberal values: Saudi Arabia is one of the world's wealthiest states, but it has a predominantly clientalist economy, which is why it produces terrorists. Rather, it is through the establishment of market economies that the United States and its allies can be made safe from terror. 